John J. Mulroy Jr. MD, ${ }^{*}$ Peter J. Davis MD, David B. Rymer MD, Kevin A. Chaitoff MD, J. Robert Boston PhD, Helen R. Westman MD, D. Ryan Cook MD

\title{
Safety and efficacy of alfentanil and halothane in paediatric surgical patients
}

\begin{abstract}
Alfentanil, a congener of the opioid fentanyl, possesse's properties that make it an attractive choice for use during short operative procedures. Since the pharmacodynamic aspects of alfentanil have not been well documented in children, this study was underiaken to evaluate the safery, efficacy, and dose requirements of alfentanil when used with nitrous oxide or halothane in paediatric patients. Eighty umpremedicated patients, ASA physical status I or II and aged 2 - 12 yrwere studied. Patients were randomly assigned to une of four groups. After induction of anaesthesia with nilrous oxide, oxygen, and halothane, the groups were treated as follows. In Group $I(n=$ 19), after halothane was discontinued, alfentanil $50 \mu \mathrm{g} \cdot \mathrm{kg}^{-1}$ was infused over 30 sec: In Group $2(n=20)$, the end-tidal halorhane was maintained at $0.5 \%$ and alfontanil $25 \mu \mathrm{g} \cdot \mathrm{kg}^{-1}$ was infused. In Group $3(n=20)$, the end-tidal halothane concentration was maintained at $1 \%$ and alfontanil $12.5 \mu \mathrm{g}$. $\mathrm{kg}^{-1}$ was infused. In Group $4(n=21)$, the end-tidal halothane concentation was maintained at $1.5 \%$ and no alfentanil was administered. Patients in Groups 1, 2, and 3 received bolus doses of alfentanil $12.5 \mu \mathrm{g} \cdot \mathrm{kg}^{-1}$ as needed to maintain haemodynamic stability. After alfe'nanil administration, there were transient decreases in systolic blood pressure in Groups I and 2, and in heart rate in Group 2. With surgical stimulation. haemodynamic stability was well maintained except in patients in Group 1, who had an increase in systolic blood pressure.
\end{abstract}

\section{Key words}

ANAESTHESIA: paediatric;

ANAESTHETICS, INTRAVENOUS: alfentanil.

From the Department of Anesthesiology and Critical Care Medicine, Children's Hospital of Pittsburgh, and University of Pittsburgh School of Medicine, Pittsburgh, Pennsylvania.

*Current address: Department of Anesthesiology, Children's Hospital and Medical Center, and University of Washington School of Medicine, Seattle, Washington.

Address correspondence to: Dr. Peter J. Davis, Deparıment of Anesthesiology and Critical Care Medicine, Children's Hospital of Pittsburgh, 3705 Fifth Avenue at DeSoto Street, Pittsburgh, PA 15213-2583.

Accepted for publication 14th January, 1991.
Children Group I were alcrt sooner and their tracheas were extubated earlier than those in Groups 2, 3, and 4. The fout groups were similar in postoperative narcotic analgesic administration and incidence of vomiting. In summary. alfentanil (12.5-50.0 $\left.\mu \mathrm{g} \cdot \mathrm{kg}^{-1}\right)$ was a safe anaesthetic, whether combined with nitrous oxide alone or with nirrous oxide and halothane.

On connait mal la pharmacocinétique de l'alfentanil chez les enfants même si cerraines des propriétés de ce parent du fentanyl devraient en favoriser l'usage lors de courles imlerventions. Nous avons donc évalué chez 80 enfants la sûreté et l' efficacié de diverses combinaisons d' alfentanil et d' halothane en présence de protoxyde d' azore. On randomisair d' abord les enfants do 2 a 12 ans et de classe ASA I ou 2 en quatre groupes. Sams prémédication, on induisait l'anesthésie de fagon habituelle avec de l'arygène, du protoxyde d'azote et de l'halothane. Puis, on cessait l'halothane chez les enfants du groupe I $(n=19)$ pour leur injecter $50 \mu \mathrm{g} \cdot \mathrm{kg}^{-1}$ d' alfentumil en 30 secondes. Pour le groupe $2(n=20)$, on ajustait l' halothane en fin d' expiration a $0,5 \%$ el on y ajoutait $25 \mu \mathrm{g} \cdot \mathrm{kg}^{-1}$ d' alfemanil. Le groupe 3 ( $=20$ ) avait une combinaison d'halohane $1,0 \%$ et 12,5 $\mu \mathrm{g} \cdot \mathrm{kg}^{-1}$ d'alfentanil et enfin, le groupe $4(n=21)$ n'avair que 1,5\% d'halothame sans alfentanil. On injectait subséquemment des doses de $12.5 \mu \mathrm{g} \cdot \mathrm{kg}^{-1}$ d'alfentanil aur enfants des groupes 1,2 et 3 afin d' assurer la stabilité hémodynamique. Transitoire ment, avec: l'injection d'alfemanil, la tension artérielle systolique diminua dans les groupes l el 2 et le pouls ralentit dans lé groupe 2. II n'y eut pas de changement hémodynamique associée à la stimulation chirurgicale sauf dans le groupe l où la rension artérielle systolique s'éleva. Les enfants du groupe I s'éveillèremt plus rapidement et purem être extubés plus tôt que ceux des autres groupes. En postopératoire, les besoins en analgésiques et l'incidence de vomissement furent semblables chez les quatre groupes. Bref, en doses de 12,5 ì $50 \mu \mathrm{g} \cdot \mathrm{kg}^{-1}$. l'alfentanil associé au protoxyde d'azote constitue un anesthésique sûr, qu'il soir ou non combiné avec de l'halothane.

Alfentanil, a congener of the opioid fentanyl, possesses pharmacokinetic properties which make it an attractive choice for use during short operative procedures. Its rapid onset, large margin of safety, small volume of distribu- 
tion, short elimination half-life, and stable haemodynamic properties have led to its use in adults both as a total opioid anaesthetic, and as an analgesic supplement to nitrous oxide anaesthesia. ${ }^{1-3}$ Although studies have revealed alfentanil to have a smaller volume of distribution and a shorter elimination half-life in children than in adults, ${ }^{4}$ the pharmacodynamic aspects of alfentanil in children have not been as well documented. This study was undertaken to evaluate the safety, efficacy, and dose requirements of alfentanil administered as a bolus, with nitrous oxide or with halothane, in paediatric patients undergoing short surgical procedures.

\section{Methods}

The study was approved by the hospital's Human Rights Committee, and informed, written consent was obtained from a parent and, when age appropriate, from the patient. Eighty unpremedicated patients of ASA physical status I or II and ages 2-I2 yr were studied. All were undergoing orthopaedic, general surgical, or otorhinolaryngologic procedures lasting less than one hour. Patients with known liver or kidney disease were excluded from the study.

Patients were routinely monitored with ECG, pulse oximetry, oscillometric measurements of blood pressure (Dinamap ${ }^{\circledR}$ ), and end-tidal gas analysis (Puritan-Bennet ${ }^{\circledR}$ Anesthetic Agent Monitor 222). General anaesthesia was induced with nitrous oxide, oxygen, and halothane by mask. An intravenous catheter was inserted and atracurium besylate, $0.5 \mathrm{mg} \cdot \mathrm{kg}^{-1}$ was administered to facilitate tracheal intubation and to prevent chest wall rigidity. After the induction of anaesthesia the patients were randomly assigned to one of four groups that differed from each other with respect to the amount of alfentanil and/or halothane that was administered.

In Group 1 (alfentanil only, $n=19$ ), halothane was discontinued following the induction of anaesthesia. With the patient breathing $70 \%$ nitrous oxide and $30 \%$ oxygen, and the end-tidal halothane concentration measuring less than $0.1 \%$, alfentanil $50 \mu \mathrm{g} \cdot \mathrm{kg}^{-1}$ was infused over 30 sec. Three minutes after the injection of alfentanil, the trachea was intubated. Anaesthesia was maintained with $70 \%$ nitrous oxide and $30 \%$ oxygen, and ventilation was controlled to maintain an end-tidal $\mathrm{PCO}_{2}$ between $30-40$ $\mathrm{mmHg}$. Increases in heart rate or systolic blood pressure greater than $20 \%$ above baseline values were treated with incremental bolus injections of $12.5 \mu \mathrm{g} \cdot \mathrm{kg}^{-1}$ of alfentanil, while decreases in heart rate of greater than $25 \%$ below baseline values were treated with $20 \mu \mathrm{g} \cdot \mathrm{kg}^{-1}$ of atropine.

Patients in Groups 2 and $3(n=20$ each) received nitrous oxide and oxygen as well as halothane and
TABLE I Demographic data

\begin{tabular}{|c|c|c|c|c|}
\hline Group & $n$ & $\begin{array}{l}\text { Age } \\
(y r)\end{array}$ & $\begin{array}{l}\text { Weight } \\
(\mathrm{kg})\end{array}$ & $\begin{array}{l}\text { Durarion of } \\
\text { anaesthesia } \\
\text { (min) }\end{array}$ \\
\hline 1 & 19 & $6.2 \pm 2.7$ & $23.3 \pm 8.5$ & $50 \pm 21$ \\
\hline 2 & 20 & $6.1 \pm 2.3$ & $21.6 \pm 6.1$ & $45 \pm 15$ \\
\hline 3 & 20 & $6.1 \pm 2.8$ & $25.3 \pm 10.6$ & $44 \pm 10$ \\
\hline 4 & 21 & $6.9 \pm 2.7$ & $25.3 \pm 10.6$ & $48 \pm 19$ \\
\hline
\end{tabular}

alfentanil. In Group 2, end-tidal halothane was maintained at $0.5 \%$ and the initial alfentanil infusion was 25 $\mu \mathrm{g} \cdot \mathrm{kg}^{-1}$. In Group 3 the end-tidal halothane concentration was maintained at $1 \%$ and the initial alfentanil infusion was $12.5 \mu \mathrm{g} \cdot \mathrm{kg}^{-1}$. As in Group 1, increases in blood pressure and heart rate greater than $20 \%$ above baseline values in Groups 2 and 3 were treated with incremental injections of $12.5 \mu \mathrm{g} \cdot \mathrm{kg}^{-1}$ of alfentanil, and decreases in heart rate greater than $25 \%$ below baseline values were treated with $20 \mu \mathrm{g} \cdot \mathrm{kg}^{-1}$ of atropine.

For patients in Group 4 (halothane only, $n=21$ ) nitrous oxide and oxygen were continued after induction and the end-tidal halothane concentration was maintained at $1.5 \%$. No alfentanil was administered. Increases in heart rate or blood pressure greater than $20 \%$ of baseline values were treated with $0.5 \%$ increments in the halothane concentration. Atropine $\left(20 \mu \mathrm{g} \cdot \mathrm{kg}^{-1}\right)$ was administered for decreases in heart rate greater than $25 \%$ below baseline values.

Haemodynamic measurements were made at the following times: on admission to the hospital (baseline), on arrival in the operating room, one minute before alfentanil injection, one minute after alfentanil injection, one minute before intubation, one minute after intubation, one minute before first surgical stimulation, and one minute after first surgical stimulation. Vital signs were recorded at five-minute intervals during the operative procedure and on admission to the postanaesthetic recovery area.

The anaesthetic gases were discontinued at the end of the surgical procedure, and residual neuromuscular blockade was antagonized. Recovery from anaesthesia was assessed by the investigators as the time from discontinuation of the last anaesthetic gas to (1) extubation and (2) alertness. Respiratory depression, evidenced by a slow respiratory rate or a requirement for a narcotic antagonist, was recorded. In the postanaesthetic recovery room, pain and vomiting were evaluated every five minutes by recovery room nurses who were unaware of group assignment. In preverbal children, pain was quantified as the use of opioid analgesics, which were administered to children who could not be comforted by swaddling, tactile soothing, or an oral pacifier. In older children opioid 
TABLE II Dose of alfentanil (mean \pm SD) and alropine requirements

\begin{tabular}{lll}
\hline Group & $\begin{array}{l}\text { Dose of } \\
\text { alfemtanil }\left(\mu \mathrm{g} \cdot \mathrm{kg}^{-1} \cdot \mathrm{min}^{-1}\right)^{*}\end{array}$ & $\begin{array}{l}\text { Number of patients } \\
\text { receiving atropine }\end{array}$ \\
\hline 1 & $1.59 \pm 0.48 \dagger$ & $6(31.5 \%)$ \\
2 & $0.79 \pm 0.29$ & $7(35.0 \%)$ \\
3 & $0.61 \pm 0.36$ & $3(15.0 \%)$ \\
4 & $0 \pm 0$ & $1(4.7 \%)$ \\
\hline
\end{tabular}

*Calculated as the total dose divided by body weight and duration of anesthesia.

+Significanlly higher than doses in Groups 2 and 3.

analgesics were administered when pain was expressed verbally. Vomiting and retching were recorded as either present or absent.

Statistical analysis included repeated measures analysis of variance, the Student-Newman-Keuls test, and the chi-square test. Significance was considered for $P<$ 0.05 .

\section{Results}

There were no statistical differences in age, weight, type of surgery, or duration of anaesthesia among the four groups (Table I). Alfentanil dosage requirements were similar in Groups 2 and 3 and significantly lower in these groups than in Group 1 (Table II). There were no statistical differences among the groups in the number of patients requiring atropine (Table II).

The haemodynamic values obtained on admission to the operating room were elevated, probably because of anxiety; therefore, the values obtained on admission to the hospital were used as the baseline values for the study. After induction of anaesthesia, but before the alfentanil injection, systolic blood pressure and heart rate remained similar to control values (Tables III and IV). After the administration of alfentanil, however, there were transient significant decreases in mean systolic blood pressure in Groups I and 2 (from 103 to $86 \mathrm{mmHg}$ and from 101 to 88 $\mathrm{mmHg}$, respectively, $P<0.01$ ) and in heart rates in Group 2 (from 108 to 83 beats per min). After tracheal intubation both heart rate and systolic blood pressure returned to near control values. With surgical stimulation, haemodynamic stability was well maintained except in patients in Group 1, who had an increase in systolic blood pressure (from 111 to $121 \mathrm{mmHg}$ ).

The patients in Group I were alert in a shorter time and the tracheas were extubated sooner than those in Groups 2-4 (Table V).

The four groups were similar in postoperative administration of narcotic analgesics. A single small dose of naloxone hydrochloride was administered to two patients in Group 1. In both these children an incremental dose of alfentanil $\left(12.5 \mu \mathrm{g} \cdot \mathrm{kg}^{-1}\right)$ had been administered less than two minutes before the completion of surgery. In both patients spontaneous ventilation resumed promptly and subsequently recovery was uneventful.

There was no difference among groups in incidence of postoperative vomiting (Table $\mathrm{V}$ ).

TABLE III Systolic blood pressure $(\mathrm{mmHg})$

\begin{tabular}{lclllllll}
\hline Group & Baseline & $\begin{array}{l}\text { On arrival } \\
\text { at OR }\end{array}$ & $\begin{array}{l}\text { Before } \\
\text { alfentanil }\end{array}$ & $\begin{array}{l}\text { Afier } \\
\text { affentanil }\end{array}$ & $\begin{array}{l}\text { Before } \\
\text { intubation }\end{array}$ & $\begin{array}{l}\text { After } \\
\text { immbation }\end{array}$ & $\begin{array}{l}\text { Before } \\
\text { incision }\end{array}$ & $\begin{array}{l}\text { Afier } \\
\text { incision }\end{array}$ \\
\hline 1 & $103 \pm 10$ & $115 \pm 14$ & $96 \pm 6$ & $86 \pm 10 \dagger$ & $90 \pm 9^{*}$ & $104 \pm 13$ & $111 \pm 13$ & $121 \pm 11^{*}$ \\
2 & $101 \pm 10$ & $117 \pm 14^{*}$ & $95 \pm 8$ & $88 \pm 9 \dagger$ & $87 \pm 8 \dagger$ & $98 \pm 10$ & $101 \pm 12$ & $111 \pm 16$ \\
3 & $98 \pm 14$ & $115 \pm 15 \dagger$ & $98 \pm 10$ & $92 \pm 16$ & $91 \pm 16$ & $97 \pm 14$ & $97 \pm 13$ & $106 \pm 15$ \\
4 & $100 \pm 8$ & $116 \pm 15^{*}$ & $92 \pm 8$ & $90 \pm 7$ & $91 \pm 8$ & $104 \pm 10$ & $98 \pm 8$ & $105 \pm 11$ \\
\hline
\end{tabular}

$m P<0.05$ vs baseline.

$\dagger P<0.01$ vs baseline.

TABLE IV Heart rale (beals per minute)

\begin{tabular}{lclllllll}
\hline Group & Baseline & $\begin{array}{l}\text { On arrival } \\
\text { at OR }\end{array}$ & $\begin{array}{l}\text { Before } \\
\text { alfentanil }\end{array}$ & $\begin{array}{l}\text { After } \\
\text { alfentanil }\end{array}$ & $\begin{array}{l}\text { Before } \\
\text { intuhation }\end{array}$ & $\begin{array}{l}\text { After } \\
\text { intubation }\end{array}$ & $\begin{array}{l}\text { Before } \\
\text { incision }\end{array}$ & $\begin{array}{l}\text { After } \\
\text { incision }\end{array}$ \\
\hline 1 & $100 \pm 16$ & $111 \pm 20$ & $88 \pm 16$ & $79 \pm 17^{*}$ & $83 \pm 17$ & $104 \pm 23$ & $114 \pm 20$ & $117 \pm 20$ \\
2 & $108 \pm 14$ & $115 \pm 23$ & $96 \pm 17$ & $83 \pm 17 \dagger$ & $84 \pm 17^{*}$ & $103 \pm 21$ & $105 \pm 24$ & $113 \pm 23$ \\
3 & $101 \pm 17$ & $113 \pm 17$ & $100 \pm 20$ & $89 \pm 23$ & $84 \pm 26$ & $106 \pm 23$ & $105 \pm 25$ & $118 \pm 27$ \\
4 & $94 \pm 19$ & $109 \pm 22$ & $91 \pm 16$ & $91 \pm 16$ & $90 \pm 17$ & $113 \pm 18$ & $100 \pm 16$ & $110 \pm 21$ \\
\hline
\end{tabular}

$* P<0.05$ vs baseline.

$\dagger P<0.01$ ys baseline. 
TABLE V Emergence limes and recovery characteristics

\begin{tabular}{|c|c|c|c|c|c|}
\hline Group & $\begin{array}{l}\text { Time ro } \\
\text { extubation }\end{array}$ & $\begin{array}{l}\text { Time to } \\
\text { alertmess }\end{array}$ & $\begin{array}{l}\text { Number of patients } \\
\text { requiring nalorone }\end{array}$ & $\begin{array}{l}\text { Number of } \\
\text { palients receiving } \\
\text { opioids in } \\
\text { the recovery room }\end{array}$ & $\begin{array}{l}\text { Number of } \\
\text { putients vomiting } \\
\text { in the recovery room }\end{array}$ \\
\hline 1 & $3 \pm 2^{*}$ & $10 \pm 9^{*}$ & $2(10 \%)$ & $5(26 \%)$ & $10(52 \%)$ \\
\hline 2 & $6 \pm 2$ & $25 \pm 11$ & $0(0)$ & $7(35 \%)$ & $11(55 \%)$ \\
\hline 3 & $8 \pm 4$ & $21 \pm 11$ & $0(0)$ & $12(60 \%)$ & $9(45 \%)$ \\
\hline 4 & $8 \pm 3$ & $24 \pm 12$ & $0(0)$ & $11(52 \%)$ & $4(19 \%)$ \\
\hline
\end{tabular}

$* P<0.05$ compared wilh Groups 2, 3, and 4 .

\section{Discussion}

Ideal intravenous anaesthetics for paediatric patients should provide an adequate depth of anaesthesia. haemodynamic stability, rapid induction and emergence, and minimal postoperative side-effects. In adult volunteers, low-dose alfentanil results in no significant haemodynamic changes. At high doses, however, alfentanil decreases heart rate, mean blood pressure, and systemic vascular resistance, and increases pulmonary capillary wedge pressure, right atrial pressure, and pulmonary vascular resistance. 5.6 Less information is available regarding alfentanil's cardiovascular effects in children. Marlow et al. reported a $20 \%$ decrease in mean arterial pressure in premature infants following a two-minute infusion of $20 \mu \mathrm{g} \cdot \mathrm{kg}^{-1}$ of alfentanil. ${ }^{7}$ In contrast, Davis et al. found no significant haemodynamic changes in premature infants receiving $25 \mu \mathrm{g} \cdot \mathrm{kg}^{-1}$ alfentanil. ${ }^{8}$

Like the other opioid compounds, alfentanil has a vagotonic effect. The differences among groups and the need for atropine following the initial dose of alfentanil did not reach statistical significance. Although the incidence of bradycardia ranged from 5 to $35 \%$, it was not statistically significant among groups. It is our belief that no matter what the aetiology, it is preferable to prevent bradycardia in all patients rather than treat it in a few. Thus, we routinely administer atropine before the injection of alfentanil.

In healthy children, $50 \mu \mathrm{g} \cdot \mathrm{kg}^{-1}$ of alfentanil as a bolus for induction of anaesthesia does not appear to suppress completely the haemodynamic response to a surgical stimulus $15 \mathrm{~min}$ later. Extrapolated data from our previous pharmacokinetic studies in children suggest that this time interval would correspond to a plasma concentration less than $200 \mathrm{ng} \cdot \mathrm{ml}^{-1}{ }^{8}$ Ausems et al. suggest that the effective plasma concentrations for $50 \%$ of patients (cp50) for intubation, lower abdominal incision, and upper abdominal incision were 425,309 , and 412 $\mathrm{ng} \cdot \mathrm{ml}^{-1}$, respectively. ${ }^{9}$ Although additional increments of $12.5 \mu \mathrm{g} \cdot \mathrm{kg}^{-1}$ controlled the hypertensive response, it appears that for procedures lasting less than one hour, either a higher initial bolus dose or a continuous infusion of alfentanil should be considered.

The mean dose requirements for alfentanil were calculated for each group by dividing the total dose of alfentanil administered during the surgery by the patient's weight and the duration of anaesthesia. The dose requirements were diminished in patients who also received halothane $\left(1.59 \pm 0.48 \mu \mathrm{g} \cdot \mathrm{kg}^{-1} \cdot \mathrm{min}^{-1}\right.$ in Group 1 vs $0.79 \pm 0.29$ $\mu \mathrm{g} \cdot \mathrm{kg}^{-1} \cdot \mathrm{min}^{-1}$ in Group $2, P<0.05$ ). The requirement of $1.59 \mu \mathrm{g} \cdot \mathrm{kg}^{-1} \cdot \mathrm{min}^{-1}$ alfentanil with nitrous oxide and oxygen is similar to that in adults. ${ }^{10}$ Although dose requirements for alfentanil decreased with increasing concentrations of inspired halothane, there were no statistical differences in dose requirements between Groups 2 and 3 . The time to extubation and time to alertness were statistically shorter in Group I than in Groups 2, 3, and 4. More rapid awakening with an alfentanil anaesthetic than with either isoflurane or halothane has been reported in adults. 11,12

Nausea, vomiting, and pain are common problems during the recovery period. The incidence of vomiting in the four groups ranged between 19 and $52 \%$, but the differences did not achieve statistical significance. Although we are unable to document a significant difference between the four groups, this may be a function of our sample size. The overall incidence in this study was $42 \%$, a value comparable to those reported in adults after alfentanil. ${ }^{10}$ Although the incidence of vomiting among children receiving alfentanil appears similar, this study may have underestimated the true incidence of postoperative vomiting, since only vomiting occurring in the recovery room was recorded. The reported incidence of postoperative vomiting following general anaesthesia in paediatric patients ranges from $5 \%$ to $42 \% .{ }^{13.14}$ In a study of paediatric outpatients, Patel and Hannallah reported that postoperative vomiting was the most frequent complication, occurring in $35 \%$ of patients, and that protracted vomiting accounted for one-third of the unscheduled admissions to the hospital following outpatient surgery. ${ }^{15}$ Postoperative vomiting following the use of 
opioids may be a major drawback to their intraoperative use. Medication with antiemetics can reduce the incidence of postoperative vomiting following anaesthesia as has been demonstrated in patients having strabismus surgery. ${ }^{16}$ However, whether such medication would be effective with other surgical procedures and with opioid anesthesia remains an important question to be answered.

The occurrence of postoperative pain in preverbal children is difficult to assess objectively. Behaviour caused by separation from parents, fear, or thirst can easily obscure or be mistaken for postoperative pain. Realizing these limitations, we indirectly assessed pain by evaluating postoperative opioid adninistration by recovery room nurses who judged the need for analgesics and were unaware of the patient's anaesthetic. In preverbal children, opioids were administered when crying could not be comforted by an oral pacifier, tactile soothing, or swaddling. The absence of significant differences in postoperative analgesic requirements between Group 1 and Groups 2, 3, and 4 may be due to the very short half-life of alfentanil. However, we cannot rule out the variability of the subjective assessment of pain by the nursing staff. Thus, patients receiving intraoperative alfentanil may still need postoperative pain medication.

In summary, we found alfentanil ( $\left.12.5-50.0 \mu \mathrm{g} \cdot \mathrm{kg}^{-1}\right)$ to be a safe anaesthetic, whether combined with nitrous oxide alone or with nitrous oxide and halothane. When used with nitrous oxide, alfentanil provided a rapid emergence from anaesthesia. An initial bolus injection of $50 \mu \mathrm{g} \cdot \mathrm{kg}^{-1}$, however, does not blunt the response to surgical incision in children. Consequently, a larger initial bolus or a continuous infusion is required.

\section{Acknowledgements}

The authors would like to thank Lisa Cohn for her editorial assistance, and Laura Dillman for her secretarial support. This project was supported in part by Janssen Pharmaceutica.

\section{References}

I Bovill JG, Sebel PS, Blackburn CL, Heykants J. The pharmacokinetics of alfentanil (R39209): a new opioid analgesic. Anesthesiology 1982; 57: 439-42.

2 Naura J, de Lange S, Koopman D, Spierdijk J, VanKleff J, Stanley $T H$. Anesthetic induction with alfentanil: a new short-acting narcotic analgesic. Anesth Analg 1982; 61: 267-72.

3 Ausems $M E$. Hug CC, de Lange S. Variable rate infusion of alfentanil as a supplement to nitrous oxide anesthesia for general surgery. Anesth Analg 1983; 62: 982-6.

4 Meistelman C, Saint-Maurice C, Lepaul M, Levron JC. Loose JP, MacGee K. A comparison of alfentanil pharmacokinetics in children and adults. Anesthesiology 1987; 66: 13-6.

5 Kay $B$, Pleuvey $B$. Human volunteer studies of alfentanil ( $R$ 39209), a new short acting narcotic analgesic.

Anaesthesia 1980; 35: 952-6.

6 Kramer M, Kling D, Waiter $P$, Borman B, Heneplema $G$. Alfentanil, a new short acting opioid: hemodynamic and respiratory aspects. Anaesthetist 1983; 32: 265-71.

7 Marlow $N$, Weindling AM, Cooke RW. Hazards of analgesia for newborn infants. Arch Dis Child 1988; 63: 1293.

8 Davis PJ, Killian A, Stiller RL, Cook DR, Guthrie RD, Scierka $A M$. Pharmacokinetics of alfentanil in newborn premalure infants and older children. Dev Pharnacol Ther 1989; 13: 21-7.

9 Ausems ME, Hug CC Jr, Stanski DR, Burm AG. Plàsma concentrations of alfentanil required to supplement nitrous oxide anesthesia for general surgery. Anesthesiology 1986; 65: 362-73.

10 White PF, Coe V, Shafer A, Sung ML. Comparison of alfentanil with fentanyl for outpatient anesthesia. Anesthesiology 1986; 64: 99- 106.

11 Cartwright DP. Recovery after anaesthesia with alfentanil or halothane. Can Anaesth Soc J 1985; 32: 479-83.

12 Short SM, Rutherfoord CF, Sebel PS. A comparison between isoflurane and alfentanil supplemented anacsthesia for short procedures. Anaesthesia 1985; 40: 1160-4.

13 Borland LM. Saitz EW, Woelfel SK. Evaluation of pediatric anesthesia care. Anesthesiology 1989; 71: A920.

14 Steward DJ. Experiences with an outpatient anesthesia service for children. Anesth Analg 1973; 52: 877-80.

15 Patel RI, Hamnallah RS. Anesthetic complications following pediatric ambulatory surgery: a 3-yr study. Anesthesiology 1988; 69: 1009-12.

16 Christensen S, Farrow-Gillespie A, Lerman J. Incidence of emesis and postanesthetic recovery after strabismus surgery in children: a comparison of droperidol and lidocaine. Anesthesiology 1989: 70: 251-4. 